\title{
BUILDING STRATEGIC PARTNERSHIP \\ OF TRANSNATIONAL EDUCATION USING ONLINE PROGRAM TO INCREASE ACADEMIC QUALITY OF GRADUATES
}

\author{
Gerardus Polla \\ Mathematics \& Statistics Department, School of Computer Science, Binus University \\ Jl. K. H. Syahdan No. 9 Palmerah Jakarta Barat 11480 \\ gerardp@binus.edu
}

\begin{abstract}
International employment standard requires higher quality of graduates, which can be achieved through high quality academic standards. As we know there are still a large number of graduates of Indonesian higher education rejected to work in global industry. Besides having low GPA, lots of graduates are considered lacking technical skills, interpersonal skills, and international experience. Indeed, the main weakness factor is the low English proficiency of graduates. We need a breakthrough that develops our academic standards of higher education to obtain international quality. Yet, there are challenges to face by the government, such as rebuilding the national system (establishing elite institutions), internationalizing higher education (globalizing the institutions or cross-border trades of education services), as well as enhancing private participation by repositioning the private sector. To overcome these challenges we need to build a strategic partnership of transnational education using online programs, which can obtain mutual benefit for the collaborating institutions. This article discusses about how to increase academic quality of graduates in Indonesia or in other Asian countries.
\end{abstract}

Keywords: academic quality, high quality graduates, strategic partnership, online programs

\begin{abstract}
ABSTRAK
Standar ketenagakerjaan internasional membutuhkan kualitas lebih dari para lulusan, yang dapat dicapai melalui standar akademik berkualitas. Seperti kita ketahui masih ada sejumlah besar lulusan pendidikan tinggi Indonesia ditolak untuk bekerja di industri global. Selain memiliki IPK yang rendah, banyak lulusan dianggap kekurangan keterampilan teknis, keterampilan interpersonal, dan pengalaman internasional. Memang, faktor kelemahan utama adalah kemampuan bahasa Inggris lulusan yang rendah. Maka dari itu kita perlu terobosan yang mengembangkan standar akademik pendidikan tinggi untuk mendapatkan kualitas internasional. Namun, ada beberapa tantangan yang harus dihadapi oleh pemerintah, seperti membangun kembali sistem nasional (mendirikan lembaga elit), internasionalisasi pendidikan tinggi (globalisasi lembaga-lembaga atau pendidikan lintas batas), serta meningkatkan partisipasi perguruan tinggi swasta dengan reposisi sektor swasta. Untuk mengatasi tantangan ini kita perlu membangun kemitraan strategis pendidikan transnasional menggunakan program online, yang dapat saling menguntungkan bagi lembaga-lembaga yang berkolaborasi. Artikel ini membahas tentang cara meningkatkan lulusan di Indonesia atau di negara-negara Asia lainnya.
\end{abstract}

Kata kunci: kualitas akademik, lulusan berkualitas, kemitraan strategis, program online 


\section{INTRODUCTION}

The development in information and communication technology (ICT) brings out significant impacts in several aspects of our lives like educational aspects. One of the biggest challenges for the higher education is that most of graduates can not be accepted in the global market (industry, international companies etc.). An international standard requires higher quality of graduates, which can be achieved through high quality standards in education. Some of the graduates lack of technical and hard skills, interpersonal skill, and international experience as well as obtain low GPA and so on. Indeed, it is what happens to Indonesian graduates that the low English competency becomes a major weakness in international competition.

How to increase academic quality of graduates? To solve these problems we need a breakthrough which can develop the international quality standards of each higher education institution. This is not easy as there are challenges to face not only by the government, but also by universities, educators, policymakers and administrators.

Government has to face some challenges, such as rebuilding the national system (establishing elite institutions), Internationalizing higher education (Globalizing the institutions or Cross-border trades of education services).

Meanwhile, universities are challenged by the rapid technological and social changes, the changing educational paradigm, the increasing significance of distance education and open learning, digitalization of learning and teaching, the chronic financial difficulties, the quest for quality and steadily increasing industrialization, as well as the commercialization and globalization. Furthermore, Industries demand for higher standards of requirements for new employees due to the ever increasing global flatness competition.

The challenges for educators are new models of teaching and professional development especially in the application of ICT, access to digital learning resources, particularly standards compliant education content, ability to track pupil progress as well as test and assess pupils online and secure, and easy-to-use education portals offering e-learning tools for interaction and collaboration.

There are also some new challenges within the educational aspects, such as: (1) changing the concept of teaching as a peripheral task to essential task; (2) reducing the number of students in a class; (3) preparing graduates for information society (preparing graduates to work in virtual companies/group); (4) creating curriculum that is variable and adaptable to current needs, so it must not only relate to individual learning requirements, but also take account of the challenges and future trends anticipation; (5) creating curriculum that is possible to impart students in cognitive, methodical and social activity skills; (6) performing cultural transformation from teaching culture to learning culture (Arnold, 1995).

Some efforts to increase academic quality of graduates are: (1) developing international quality standards of each higher education; (2) rebuilding the national system (establishing elite institutions) and internationalizing higher education (globalizing the institutions or cross-border trades of education services); (3) enhancing private party participation by repositioning the private sector; (4) increasing the demand for higher academic quality including human resources and supporting facilities, curriculum which is recognized at international level; (5) establishing international collaboration in research and publication and strategic alliances that develop twinning programs and so on. Other pathway of foreign universities entering Indonesia is to establish strategic alliances. A latest trend is to have strategic alliances for $3+1$ year method, or fast-track with double degree combining Bachelor and Master degree. Apart from that, another thing to do is increasing the number of 
international education exhibitions which offers pathway via scholarships to grab the best students; some universities enthusiastically do promotion and marketing in Indonesia and other countries.

In this case we need to build a strategic partnership of Transnational Education (TNE) using Online Program which can give mutual benefit for two institutions. The strategies include the implementation of online program to develop new programs, services, products and processes for the students. Another strategic is building strategic Partnership of TNE and strategies for Curriculum internationalization.

\section{METHOD}

\section{Definition and Characteristic of Transnational Education}

Transnational Education (TNE) is all types of higher education study programmes, or sets of courses of study, or educational services (including those of distance education) in which the learners are located in a country different from the one where the awarding institution is based. Such programmes may belong to the education system of a State different from the State in which it operates, or may operate independently of any national education system (UNESCO, 2001).

There are some other view points on Transnational Education (TNE). TNE implies crossing the borders of national higher education systems; it falls within the category of non-official higher education, which in its turn is defined as "all forms of higher education activities operating in parallel to and outside the official higher education system of the host country". TNE refers to the delivery of distance education to students in a country different from that of the offering institution. It can be executed through online program. TNE refers to those courses of study, parts of courses of study, or other educational services in which the students are located in outside the country where the institution providing the services is based (UNESCO-CEPES, 2000; GATE, 1997). TNE is a key component of the international trade of education within the framework of the World Trade Organization (WTO).

Additionally, Transnational Education should comply with the national legislation on higher education in both sending and receiving countries. The academic quality and standards of TNE programs should be at least comparable to those of the home institution as well as to those of the host country. TNE institutions should publish their policy and mission statements; their information should be transparent, consistent and reliable. Staff members of TNE institutions should be proficient in terms of qualifications, teaching, research and other professional experience

Types of Transnational Education are; (1) international institutions; (2) distance learning or/and virtual universities; (3) branch campuses; (4) program articulations/twinning degrees; (5) offshore institutions; (6) franchises.

Three main forms of TNE are: (1) international distance education, in which students are supported remotely from the home; (2) combination of communication tools and sometimes short visits at campuses; (3) Partner-supported programs, in which the provider collaborates with a local partner to share the delivery of services to students; (4) international branch campus, in which a provider establishes an overseas subsidiary to teach students in that country.

\section{Why Transnational Education (TNE)?}

First is because the scope of TNE is globalisation and/or internationalization. Globalization is transforming the societies and driving a revolution in various aspects of human life. Because two of 
the main bases of globalization are knowledge intensive information and innovation, globalization is believed to have a profound impact on higher education in general (Carnoy, Currie and Scott, 1998). Second is due to demand and market-driven supply. Third is that TNE grows rapidly (worldwide).

\section{International Standards for TNE}

The most important statement of international standards in transnational education is "Guidelines for Quality Provision in Cross-Border Higher Education”, stated by UNESCO and the OECD in 2005. The guidelines set out minimum standards in order to 'provide an international framework to protect students and other stakeholders from low-quality provision and disreputable providers'. Some major exporting countries have developed binding guidelines for their provider's operative offshore.

\section{Developing a Transnational Education Strategy}

In relation to prospective offshore students and their families, a transnational program will: (1) broaden access to education; (2) provide a type of education that is not currently available, or insufficient to cover the demand; (3) respond to the learners' educational demands; contribute to their cognitive, cultural, social, personal and professional development. In relation to the awarding institution, an offshore initiative will: (1) build on an existing strength; (2) be noticed by staff as a worthwhile and rewarding activity; (3) improve the institution's reputation; (4) help or hinder efforts to meet the institution's key strategic objectives.

\section{RESULTS AND DISCUSSION}

\section{Building Strategic Partnership of TNE}

\section{Strategies for Curriculum Internationalization}

Strategy to develop internationalized curriculums is an important issue in teaching and learning reform for universities worldwide. There are two major reasons for pursuing curriculum internationalization. First is to become a world class institution attracting more overseas students to study on-campus. Second is to accommodate a diversified international student organization oncampus and in transnational provisions overseas. Preparing graduates to be "internationally knowledgeable and intercultural competent can be done through two approaches: (1) soft approach, e.g. international student and staff exchange; (2) hard approach, i.e. undertaking curriculum change. A process of planning for organizational change involves dedicated leadership, resource commitment, involvement and support of academic staff. However, in implementing the process there will be some challenges, such as; (1) putting policy into practice; (2) developing staff capacity; (3) focusing on the desired learning outcomes (Leask, 1999).

However, the preparation sometimes gives difficulties to developers, such as: (1) dealing with market with little knowledge or unfamiliarity to the online/e-learning program; (2) developing a qualified and acceptable online/e-learning program; (3) similar program for professionals found at Many other universities.

\section{Multi Channel Learning (MCL)}

Teaching and Learning process in BINUS University are applied using the Multi Channel Learning (MCL) method, which has been implemented under various conditions such as fully on line 
and partially on line. It has been started in 2003 until now and it has grown so fast. Binus University development best practices for course content development process consists of interrelated artifacts as: lecture notes; multimedia visualizations; and additional resources \& URLs, etc.

Multi-Channel Learning (MCL) is a combination of face to face and e-learning method that enable students to establish self learning habit which would cultivate the continuous long-life learning culture. MCL is implemented in all of faculties, which is run on approximately $40 \%$ of our courses.

Meanwhile, the Learning Management System (LMS) is totally built by Binus internal IT team. In March 2011 Binus launched the 5th version of LMS. Each of our students and lecturers are provided by their personal website/homepage, in which the students can download the courses materials, courses schedule as well as manage their credits per semester, payment, and monitor their grades.

\section{Good Practices of BINUS Online Learning Using MCL}

BINUS Online Learning is a learning model by ways of electronic means, supported by the websites www.online.binus.edu or www.online.binus.ac.id. As a learning tool, Binus Online Learning is specialized for individual learning and development without the rigid class schedule. This method is very suitable for students who are professional workers and entrepreneurs, or even housewives who want to pursue their bachelor degrees without having to leave the house often. Much of the learning activities are focused on the students' learning style and the quality of the lecturers as well as the practitioners to enhance the finishing time of study.

Binus online learning is proved advantageous since: (1) it offers the most flexible learning mode compared to other institutions. For example: at BINUS Online Learning class, every student works on his/her assignments on time. There is not any complaint about the learning process; (2) it is fully supported by excellent information technology. Therefore the learning process can run smoothly. Besides, Binus Online Learning makes ways the process of learning materials update that enriches lecturers with knowledge. Accordingly, more knowledge could be applied to the industry; (3) the lecturers are the experts in each field or subject; (4) motivation is the core issue in learning. It is the fact that the levels of fondness of BINUS Online students are high. It is also strengthened by the results of the study from the scores gained by the students; (5) students of BINUS Online mostly are professionals who are courageous, highly motivated and proactive in learning, and have good time management. These have resulted in the high competitiveness of BINUS Online learning students; (6) the students are facilitated to learn from many different sources to enhance applicability and rich array of knowledge.

\section{CONCLUSIONS}

From the discussion above, it can be concluded that: (1) TNE refers to the delivery of distance education to students out of country of the offering institution. It can be established by online program; (2) TNE is a key component of the international trade of education within the framework of the World Trade Organization (WTO); (3) academic quality and standards of TNE programs should be at least comparable to those of the home institution as well as to those of the host country; (4) most institutions have introduced ICT-based programs and services in pursuit of quality improvement and expansion; (5) some new collaborative partnerships have been emerged. Such partnerships include private and public collaboration, for-profit and non-for-profit collaboration, regional and international collaboration; (6) Binus online learning has been succesfully implemented and the success factors are: flexible learning method compared to other institutions, full support from the information technology, 
rich and applicable learning that students are facilitated to learn from many different sources using multi channel learning (MCL); Technology can never be a substitute for teachers, but it can help to provide more enriching educational experience.

\section{REFERENCES}

Davis, D., \& Meares, D. (2001). Transnational Education: Australia Online Critical Factors for Success. Sydney: IDP Education Australia.

IDP Education Australia (2000). Transnational education providers, partners and policy: Challenges for Australian institutions offshore. D. Davis, A. Olsen \& A. Bohm (Eds.). IDP: Canberra.

McBurnie, G., \& Pollock, A. (2000). Opportunity and Risk in Transnational Education - Issue in Planning for International Campus Development: An Australian perspective. Higher Education in Europe, 25(3), 333-343.

Ziguras, Christopher. (2001). Good Practice in Transnational Education: A guide for New Zealand Providers. Melbourne: Royal Melbourne Institute of Technology. 